\title{
ANALISIS AGRIBISNIS UBI JALAR UNGU DI DESA TELADAN KECAMATAN CURUP SELATAN KABUPATEN REJANG LEBONG
}

\section{ANALYSIS OF AGRIBUSINESS OF UBI JALAR UNGU IN TELADAN VILLAGE SOUTH CURUP SUBDISTRICT REJANG LEBONG DISTRICT}

\author{
Yeni Marlina, Putri Suci Asriani, Bambang Sumantri \\ Program Pascasarjana Magister Agribisnis \\ Fakultas Pertanian Universitas Bengkulu
}

\begin{abstract}
The aims of the research are to 1) determine factors that affect the production of ubi jalar ungu, 2) to know how much costs and revenues the ubi jalar ungu farming, 3) to determine the efficiency of the ubi jalar ungu farming, 4) to calculate how much added value from ubi jalar ungu processing into fried macaroni. This study sites was intentionally set in the village of Teladan. The data is obtained from the primary data and the secondary data, the respondents of ubi jalar ungu farmers was taken by census method. While the processor is home industry ZAHRA. The result shows that significant factos are seeds, Phonska fertilizers, manures and labors. While, land factor is not significant. The total cost for the ubi jalar ungu farming is $R p$ 2.900.054,13/Ut/Mt or $R p$ 8.209.106,83/Ha/Mt, and a revenue is $R p$ 3.241.570,87/Ut/Mt, or Rp 9.190.226,51/Ut/Ha. Result of the R/C ratio is 2,12, and the value is greater than one. It means that the farming is efficient. The added value of ZAHRA home industry is $R p 41.072,-/ \mathrm{kg}$, with a profit of $R p 37.472,-/ \mathrm{kg}$, and the rate of profit reaches $91.23 \%$. This benefit is a net plus, because it has been reduced by the share of the labor.
\end{abstract}

Key words: Ubi jalar ungu, production, revenue, efficiency and value-added

\section{PENDAHULUAN}

Sejalan dengan meningkatnya jumlah penduduk Indonesia, maka kebutuhan akan pangan semakin meningkat. Alternatif solusi untuk mengatasi masalah pertumbuhan konsumsi adalah program diversifikasi pangan. Kebijakan untuk mewujudkan adanya diversifikasi dapat dilaksanakan melalui (a) pengembangan konsumsi pangan karbohidrat yang beragam, (b) pengembangan dan peningkatan daya tarik pangan karbohidrat non beras, dan (c) pengembangan produk dan mutu produk pangan karbohidrat non beras 
yang bergizi tinggi dan memungkinkan untuk dikembangkan (Nurmalina, 2008).

Salah satu produk bahan sumber pangan karbohidrat non beras yang dikembangkan dan diolah para petani adalah ubi jalar ungu di Kecamatan Curup Selatan merupakan salah satu sentra penghasil ubi jalar ungu terbesar di Kabupaten Rejang Lebong yaitu berada pada Desa Teladan. Usahatani ubi jalar ungu ini dibudidayakan secara tradisional yang sebagian besar dilaksanakan oleh petani ubi jalar secara turun temurun. Mengingat sifat produk pertanian yang tidak tahan lama maka peran agroindustri sangat diperlukan. Ubi jalar ungu merupakan salah satu tanaman pangan yang memiliki banyak kelebihan. Misalnya saja pada saat cadangan makanan (padi-padian) mangalami kekurangan, ubi jalar ungu masih dapat diandalkan sebagai sumber bahan pengganti karena ubi jalar merupakan tanaman yang tahan kekurangan air sehingga masih dapat diproduksi di lahan kritis sekalipun dan cara penanaman ubi jalar pun tergolong sangat mudah. Pada desa Teladan terdapat industri rumah tangga pengolahan ubi jalar ungu yang diharapkan dapat memberikan nilai tambah. Dengan adanya industri rumah pengolahan ubi jalar ungu dapat memotivasi petani untuk membudidayakan ubi jalar ungu secara kontinu dan bisa meningkatkan usahataninya agar produksi yang dihasilkan dapat memberikan keuntungan bagi petani dan ketersedian bahan baku pada industri rumah terpenuhi. Berdasarkan uraian di atas tujuan dari penelitian ini adalah: (1) Mengetahui faktor-faktor yang mempengaruhi produksi ubi jalar ungu, (2) Mengetahui berapa besar biaya dan pendapatan petani ubi jalar ungu, (3) Mengetahui apakah usahatani ubi jalar ungu sudah efisien dan mengguntungkan, dan (4) Menghitung Berapa besar nilai tambah yang diperoleh dari pengolahan ubi jalar ungu menjadi makaroni goreng di desa Teladan Kecamatan Curup Selatan Kabupaten Rejang Lebong.

\section{METODE PENELITIAN}

Metode analisis yang digunakan pada penelitian ubi jalar ungu ini adalah analisis secara kualitatif maupun kuantitatif. Penentuan lokasi penelitian ini ditentukan dengan secara sengaja (purposive) yaitu Desa Teladan. Responden dalam penelitian ini terdiri dari petani dan pengolah ubi jalar ungu. Responden petani adalah petani yang menanam ubi jalar ungu secara kontinu, sedangkan responden pengolah ubi jalar ungu adalah industri rumah tangga ZAHRA yang melakukan pengolahan ubi jalar ungu menjadi makaroni yang diharapkan dapat memberikan nilai tambah. Pengambilan responden dilakukan dengan metode sensus, sedangkan sampel industri rumah tangga ditentukan secara sengaja (purposive) pada industri rumah tangga ZAHRA (Nazir, 1983). Sumber data adalah data primer dan data skunder. Penelitian ini 
menggunakan fungsi produksi Cobb-Douglas, dengan mengunakan model Analisis Regresi. Secara matematis fungsi produksi Cobb-Douglas dapat dirumuskan sebagai berikut:

$$
Y=b 0 X_{1}{ }^{b 1} X_{2}{ }^{b 2} X_{3}{ }^{b 3} X_{4}{ }^{b 4} \quad e^{u}
$$

Keterangan : $\mathrm{Y}=$ Produksi, $\mathrm{X}_{1}=$ Bibit, $\mathrm{X}_{2}=$ Pupuk phonska, $\mathrm{X}_{3}=$ Pupuk kandang, $\mathrm{X}_{4}=$ Tenaga kerja, $\mathrm{b}_{0}$ dan $\mathrm{b}_{1}=$ besaran yang akan diduga, $\mathrm{e}=$ standar eror/bilangan natural, $\mathrm{u}=$ Unsur sisa (galat).

Untuk mencari besarnya biaya dan pendapatan usahatani ubi jalar ungu dengan menggunakan rumus sebagai berikut:

$$
\begin{aligned}
& \text { Pd }=\text { TR }- \text { TC } \\
& \text { Pn }=\text { Y x Py } \\
& \text { TC }=\text { FC + VC }
\end{aligned}
$$

Dimana: $\mathrm{Pd}=$ Pendapatan $(\mathrm{Rp} / \mathrm{Mt}), \mathrm{Pn}=$ Penerimaan $(\mathrm{Rp} / \mathrm{Mt}), \mathrm{TC}=$ Total biaya $(\mathrm{Rp} / \mathrm{Mt}), \mathrm{FC}=$ Biaya tetap $(\mathrm{Rp} / \mathrm{Mt}), \mathrm{VC}=$ Biaya variabel $(\mathrm{Rp} / \mathrm{Mt}), \mathrm{Y}=$ Jumlah produksi yang dihasilkan $(\mathrm{Kg} / \mathrm{Mt})$, Py = Harga Jual $(\mathrm{Rp} / \mathrm{Kg})$. Untuk mengetahui efisiensi usahatani ubi jalar ungu digunakan analisis $\mathrm{R} / \mathrm{C}$ Ratio. Untuk mengetahui nilai tambah dari pengolahan ubi jalar ungu menjadi makaroni goreng digunakan analisis nilai tambah menurut Hayami (1987).

\section{HASIL DAN PEMBAHASAN}

\section{Karakteristik Petani Petani Ubi Jalar Ungu Di Desa Teladan}

Karakteristik petani dalam penelitian ini meliputi umur, tingkat pendidikan, pengalaman berusaha, jumlah anggota keluarga, dan luas lahan yang digunakan untuk menanam ubi jalar ungu. Karakteristik petani ubi jalar ungu dapat dilihat pada Tabel 1.

Tabel 1 menunjukkan umur petani ubi jalar ungu di daerah penelitian berkisar 23-65 tahun dengan rata-rata usia petani adalah 45,63 tahun. Dengan demikian petani ubi jalar ungu berada pada usia produktif, dan dalam usia ini diharapkan petani mampu melakukan produksi secara maksimal. Hal ini sejalan dengan pendapat Mubyarto (1984) yang menyatakan usia produktif yaitu usia 15-59 tahun, dimana pada usia ini petani akan memberikan hasil yang maksimal jika dibandingkan pada masa usia di bawah dan di atas usia produktif. Petani yang telah berusia tua (51-65) tahun dan masih tetap berusahatani ubi jalar ungu beranggapan bahwa bertani merupakan mata pencarian utama yang telah turun menurun. 
ISSN: $1412-8837$

Tabel 1. Karakteristik Petani Ubi Jalar Ungu di Desa Teladan

\begin{tabular}{|c|c|c|c|c|}
\hline No & Uraian & $\begin{array}{l}\text { Jumlah } \\
\text { (orang) }\end{array}$ & $\begin{array}{c}\text { Persentase } \\
(\%)\end{array}$ & Rata-rata \\
\hline \multirow[t]{5}{*}{1} & Umur (Tahun) & & & 45,63 \\
\hline & $23-36$ & 6 & 15,00 & \\
\hline & $37-50$ & 24 & 60,00 & \\
\hline & $51-65$ & 10 & 25,00 & \\
\hline & Jumlah & 40 & 100,00 & \\
\hline \multirow[t]{5}{*}{2} & Tingkat Pendididkan & & & 7,75 \\
\hline & $4-6$ & 24 & 60,00 & \\
\hline & $7-9$ & 8 & 20,00 & \\
\hline & $10-12$ & 8 & 20,00 & \\
\hline & Jumlah & 40 & 100,00 & \\
\hline \multirow[t]{6}{*}{3} & Berusahatani & & & 14,03 \\
\hline & (Tahun) & 28 & 70,00 & \\
\hline & $4-15$ & 10 & 25,00 & \\
\hline & $16-27$ & 2 & 5,00 & \\
\hline & $28-40$ & & & \\
\hline & Jumlah & 40 & 100,00 & \\
\hline \multirow[t]{5}{*}{4} & Jumlah Anggota Keluarga (orang) & & & 3,93 \\
\hline & $2-3$ & 11 & 27,50 & \\
\hline & $4-5$ & 27 & 67,50 & \\
\hline & $6-7$ & 2 & 5,00 & \\
\hline & Jumlah & 40 & 100,00 & \\
\hline \multirow[t]{5}{*}{5} & Luas Tanam (Ha) & & & 0,36 \\
\hline & $0,25-0,50$ & 38 & 95,00 & \\
\hline & $0,51-0,76$ & 2 & 5,00 & \\
\hline & $0,77-1,01$ & 0 & 0 & \\
\hline & Jumlah & 40 & 100,00 & \\
\hline \multirow[t]{5}{*}{6} & Status Kepemilikan Lahan & & & Milik Sendiri \\
\hline & Milik sendiri & 40 & 100,00 & \\
\hline & Sewa/gadai & 0 & 0 & \\
\hline & Penggarap & 0 & 0 & \\
\hline & Jumlah & 40 & 100,00 & \\
\hline
\end{tabular}

Sumber: Data Primer Diolah, 2013

Tingkat pendidikan adalah salah satu faktor penujang keberhasilan petani dalam melaksanakan usahataninya, karena tingkat pendidikan sangat mempengaruhi pada tingkat kemampuan petani dalam bertindak dan mengambil keputusan seperti menyerap inovasi, teknologi dan ilmu pengetahuan dalam mengelola usahataninya. Rata-rata tingkat pendidikan yang ditempuh petani ubi jalar ungu di daerah penelitian yaitu 7,75 tahun namun petani bisa menulis dan membaca. Persentase tingkat petani terbesar berada pada tingkat pendidikan 4-6 tahun yaitu sebanyak 60 persen. Hal ini

88 | Yeni Marlina, Putri Suci Asriani, Bambang Sumantri. Kajian ..... 
menunjukkan bahwa tingkat pendidikan masih rendah yaitu pada tingkat SD, karena alasan petani masih kekurangan biaya untuk melajutkan pendidikan.

Pengalaman berusahatani yang dimaksud dalam penelitian ini adalah lamanya petani dalam melaksanakan usahatani. Hal ini menujukan bahwa semakin lama petani memiliki pengalaman, maka petani akan lebih paham mengenai praktek berusahatani ubi jalar ungu. Berdasarkan Tabel 1, rata-rata pengalaman berusahatani ubi jalar ungu sudah lama yaitu 14,03 tahun. Pengalaman usahatani terbesar yaitu 4 - 15 tahun, sebanyak 70 persen dari jumlah responden. Pengalaman berusahatani diperoleh petani dari orang tua atau turun-temurun.

Pada Tabel 1 juga diketahui bahwa jumlah tanggungan keluarga petani ubi jalar ungu di daerah penelitian rata-rata 4 orang. Jumlah tanggungan keluarga termasuk dalam jumlah keluarga sedang, bekisar antara 4-5 orang yaitu 27 orang dari jumlah responden atau mencapai 67,50 persen. Menurut Soekartawi (1990), faktor produksi tenaga kerja merupakan faktor produksi yang penting dan perlu diperhitungkan dalam proses produksi. Bukan saja dilihat dari tersedianya tenaga kerja tetapi juga kualitas dan macam tenaga kerja perlu pula diperhatikan, sehingga dalam hal ini jumlah anggota keluarga yang berusia produktif juga akan berperan dalam menyediakan tenaga kerja untuk kegiatan usahatani. Semakin banyak jumlah anggota keluarga yang produktif maka banyak tenaga yang tersedia untuk membantu kegiatan berusahatani sehingga dapat mengurangi biaya tenaga kerja.

Luas lahan terbanyak yang diusahakan untuk usahatani ubi jalar ungu adalah luas lahan antara 0,25-0,75 $\mathrm{Ha}$, yaitu sebesar 95,00 persen atau sebanyak 38 orang petani. Luasan lahan yang tergolong sempit ini dikarenakan petani membagi lahan untuk tanaman lainya. Menurut petani resoponden luas lahan di daerah penelitian untuk pertanian semakin hari semakin berkurang. Hal tersebut karena selain adanya sistem hak waris dan juga para petani di Desa Teladan sudah banyak yang tergiur untuk menjual lahan pertaniannya. Status kepemilikan lahan petani ubi jalar ungu adalah 100 persen milik sendiri. Status kepemilikan sendiri ini terdiri dari pembelian ataupun dari warisan orang tua.

\section{Analisis Faktor-Faktor Yang Mempengaruhi Produksi Ubi Jalar Ungu}

Analisis dalam kegiatan produksi ubi jalar ungu di Desa Teladan dilakukan dengan memperhitungkan tingkat input yang digunakan terhadap tingkat produksi yang diperoleh. Model untuk menganalisis atau mengestimasi fungsi produksi usahatani ubi jalar ungu adalah model Fungsi Cobb-Douglas dengan menggunakan metode kuadrat terkecil (Ordinary least square). Faktorfaktor produksi pada penelitian yang diduga berpengaruh nyata terhadap produksi ubi jalar ungu adalah penggunaan bibit, pupuk phonska, pupuk kandang, dan tenaga kerja. Dari hasil regresi diperoleh estimasi sebagai berikut. 
Tabel 2. Hasil Pendugaan produksi Cobb-Douglas pada Usahatani Ubi Jalar Ungu

\begin{tabular}{llccc}
\hline No & Variabel Bebas & Koefisien Regresi & t hitung & \multirow{2}{*}{ VIF } \\
\hline \multicolumn{1}{c}{ Intercept } & 3,094 & 6,294 & \\
1 & Bibit $\left(\mathrm{X}_{1}\right)$ & $0,284^{* *}$ & 2,357 & 5,857 \\
2 & Pupuk Phonska $\left(\mathrm{X}_{2}\right)$ & $0,277^{\text {** }}$ & 2,200 & 6,241 \\
3 & Pupuk Kandang $\left(\mathrm{X}_{3}\right)$ & $0,185^{\mathrm{ns}}$ & 1,671 & 4,893 \\
$4 \quad$ Tenaga Kerja $\left(\mathrm{X}_{4}\right)$ & $0,200^{*}$ & 1,992 & 3,931 \\
\hline R Square & & 0,899 & \\
F-hitung & & 77,896 & \\
F-tabel & & 2,640 & \\
\hline
\end{tabular}

Sumber: Data Primer Diolah, 2013

Keterangan:

$\left.{ }^{* *}\right)$ signifikan pada tingkat $90 \% \quad:$ a/2 $=0,05$

*) signifikan pada tingkat $80 \% \quad: a / 2=0,10$

ns) tidak signifikan

Hasil pendugaan model fungsi produksi menunjukan bahwa nilai koefisien determinasi $\left(R^{2}\right)$ sebesar 0,899 atau 89,90 persen dengan nilai determinasi terkolerasi ( $R^{2}$ adj) sebesar 88,70 persen. Nilai determinasi $\left(R^{2}\right)$ tersebut memiliki arti bahwa sebesar 89,90 persen dari variasi produksi dapat dijelaskan secara bersama-sama oleh model, sedangkan sisanya sebesar 10,10 persen dijelaskan oleh faktor lain di luar model. Faktor lain tersebut yang diduga berpengaruh terhadap produksi ubi jalar ungu antara lain pengaruh iklim dan cuaca, tingkat kesuburan tanah, serta intensitas serangan hama dan penyakit tanaman, teknologi, modal, dan manajemen. Hasil nilai uji-F menunjukkan hasil $\mathrm{F}_{\text {hitung }}$ pada model pendugaan fungsi produksi mencapai 77,896, sedangkan nilai $F_{\text {tabel }}$ yaitu 2,640, sehingga $F_{\text {hitung }}>F_{\text {tabel. }}$ Kondisi ini menjelaskan bahwa semua faktor produksi yang digunakan dalam usaha ubi jalar ungu secara bersama-sama memiliki pengaruh yang nyata terhadap produksi ubi jalar ungu pada selang kepercayaan 95\% ( $\alpha=0,05)$. Uji-t dapat digunakan untuk melihat apakah ada pengaruh nyata dari masing-masing variabel bebas (input produksi) yang digunakan secara terpisah terhadap variabel tidak bebas (output) yaitu dengan membandingkan $t_{\text {hitung }}$ dengan $t_{\text {tabel. }}$. Uji-t menunjukan bahwa variabel bebas yang berpengaruh nyata pada taraf kepercayaan $80 \%$ adalah tenaga kerja sedangkan untuk taraf kepercayaan $90 \%$ yang berpengaruh nyata adalah bibit dan pupuk phonska. Untuk hasil uji terhadap pupuk kandang memiliki nilai $t_{\text {hitung }}$ lebih kecil dari $t_{\text {tabel. }}$ Kondisi ini menunjukan bahwa pupuk kandang tidak berpengaruh nyata dalam produksi ubi jalar ungu di Desa Teladan. 
Bibit dari nilai bahwa nilai $t_{\text {hitung }}>t_{\text {tabel }}$ dengan taraf kepercayaan $90 \%$ $(a / 2=0,05)$ yaitu 2,357 $>2,030$. Berdasarkan uji hipotesis maka tolak H0 dan terima $\mathrm{Ha}$, artinya penggunaan bibit ubi jalar ungu berpengaruh nyata terhadap produksi ubi jalar ungu. Hasil estimasi koefisien regresi bibit adalah 0,284 yang berarti bahwa setiap peningkatan penggunaan variabel bibit sebesar 100 persen akan meningkatkan jumlah produksi sebesar 28,40 persen, dengan asumsi semua variabel lain tetap (cateris paribus). Rata-rata penggunaan bibit per musim tanam yang digunakan petani ubi jalar ungu sebesar 1429,92 $\mathrm{Kg} / \mathrm{Ha} / \mathrm{Mt}$, sedangkan standar penggunaan bibit menurut menurut Rukmana (1997), jumlah bibit yang direkomendasikan untuk penanaman ubi jalar ungu adalah sebanyak $1.500 \mathrm{Kg} / \mathrm{Ha}$ dengan jarak tanam yang sama. Berdasarkan rekomendasi penggunaan bibit, di lokasi penelitian masih bisa untuk ditambah. Penggunaan bibit di daerah penelitian sesuai dengan kebutuhan bibit per hektar yang direkomendasikan. Menurut petani karena mereka ragu apakah bibit akan hidup semuanya dan manghasilkan semua, karena bibit merupakan turunan lokal, dan mereka beranggapan bahwa makin banyak bibit akan makin banyak pula hasil umbi yang diperoleh dan dengan panjang jarak tanam maka akan menghasilkan umbi yang banyak. Hal ini menunjukkan bahwa penggunaan bibit yang digunakan petani ubi jalar ungu sudah sesuai aturan.

Pupuk Phonska, $t_{\text {hitung }}>t_{\text {tabel }}$ dengan taraf kepercayaan $90 \%(\alpha / 2=0,05)$ yaitu 2,200 $>2,030$. Berdasarkan uji hipotesis maka tolak $\mathrm{H} 0$ dan terima Ha, artinya penggunaan faktor produksi pupuk phonska berpengaruh nyata terhadap produksi ubi jalar ungu. Hasil estimasi koefisien regresi pupuk phonska adalah 0,277 yang berarti jika terjadi penambahan pupuk phonska sebesar 100 persen maka akan meningkatkan produksi ubi jalar ungu sebesar 27,70 persen, dengan asumsi semua variabel lain tetap (cateris paribus). Ratarata penggunaan pupuk phonska untuk satu kali tanam oleh petani ubi jalar ungu yaitu sebanyak 68,50 kilogram (191,67 kg per hektar), sedangkan standar penggunaan phonska menurut Rukmana (1997) sebanyak 200 kg per hektar.

Pupuk Kandang, dari uji-t penggunaan pupuk kandang menunjukkan $t_{\text {hitung }}<t_{\text {tabel }}$ pada taraf kepercayaan 80\% $(\alpha / 2=0,10 \%)$ yaitu $1,671<1,689$. Berdasarkan uji hipotesis maka terima $\mathrm{H} 0$ dan tolak $\mathrm{Ha}$, artinya penggunaan pupuk kandang berpengaruh tidak nyata terhadap produksi ubi jalar ungu. Sehingga pengurangan atau penambahan pupuk kandang tidak akan mengakibatkan perubahan secara signifikan terhadap produksi ubi jalar ungu. Rata-rata petani ubi jalar ungu menggunakan pupuk kandang untuk satu kali tanam sebanyak 3.678,17 kilogram per hektar, sedangkan standar penggunaan pupuk kandang menurut Sarwono (2005) sebesar 4.000 kilogram per hektar.

Tenaga Kerja, hasil uji-t diperoleh bahwa $t_{\text {hitung }}>t_{\text {tabel }}$ pada taraf kepercayaan $80 \%(\alpha / 2=0,10)$ yaitu $1,992>1,689$. Berdasarkan uji hipotesis maka tolak $\mathrm{H} 0$ dan terima $\mathrm{Ha}$, artinya bahwa penggunaan faktor produksi 
tenaga kerja berpengaruh nyata terhadap produksi ubi jalar ungu. Nilai koefisien regresi dari penggunaan tenaga kerja mencapai 0,200, artinya jika terjadi penambahan tenaga kerja sebesar 100 persen maka akan meningkatkan produksi ubi jalar ungu sebesar 20 persen dengan asumsi variabel lain tetap (cateris paribus).

\section{Analisis Penggunaan Biaya dan Faktor Produksi}

Penggunaan faktor produksi pada kegiatan usahatani merupakan hal yang sangat penting karena akan mempengaruhi produksi yang dihasilkan. Atas penggunaan faktor-faktor produksi tersebut akan muncul biaya produksi. Biaya produksi adalah semua biaya yang diperlukan untuk menghasikan produk yang terdiri dari biaya tetap dan biaya variabel. Biaya tetap pada penelitian ini terdiri dari biaya penyusutan alat, pajak lahan atau sewa lahan. Sedangkan biaya variabel adalah bibit, pupuk, dan tenaga kerja. Rata-rata penggunaan faktor produksi dapat dilihat pada Tabel 3.

Tabel 3. Rata-rata Penggunaan Faktor Produksi dan Biaya Usahatani Ubi Jalar Ungu

\begin{tabular}{|c|c|c|c|c|c|}
\hline \multirow{2}{*}{ Faktor produksi } & \multirow{2}{*}{ Fisik/Ut } & \multirow{2}{*}{$\begin{array}{c}\text { Fisik/H } \\
\text { a }\end{array}$} & \multicolumn{3}{|c|}{ Biaya } \\
\hline & & & $\mathrm{Rp} / \mathrm{Ut}$ & $\mathrm{Rp} / \mathrm{Ha}$ & $\%$ \\
\hline \multicolumn{6}{|l|}{ Input Variabel (VC) } \\
\hline 1. Bibit $(\mathrm{Kg})$ & 509,81 & 1429,92 & $37.816,38$ & $105.198,87$ & 1,70 \\
\hline 2. Pupuk phonska (Kg) & 68,50 & 191,67 & $174.537,50$ & $486.833,33$ & 7,88 \\
\hline 3. Pupuk kandang $(\mathrm{Kg})$ & $1.311,63$ & 3678,17 & $232.293,93$ & $667.483,92$ & 10,81 \\
\hline $\begin{array}{l}\text { 3. Tenaga Kerja dalam } \\
\text { keluarga (HKSP) }\end{array}$ & 50,38 & 143,07 & $1.739 .250,00$ & $4.917 .166,67$ & 79,61 \\
\hline Total Biaya Variabel & & & $2.183 .897,82$ & $6.176 .682,80$ & 100,00 \\
\hline \multicolumn{6}{|l|}{ Input Tetap } \\
\hline 1. Sewa lahan (Rp) & - & - & $656.250,05$ & $1.850 .000,27$ & 91,02 \\
\hline 2. Pajak (Rp) & - & - & $6.563,98$ & $14.019,79$ & 0,69 \\
\hline $\begin{array}{l}\text { 3. Penyusutan Alat } \\
(\mathrm{Rp})\end{array}$ & - & - & $53.342,29$ & $168.403,97$ & 8,29 \\
\hline Total Biaya Tetap (FC) & & & $716.156,31$ & $2.032 .424,03$ & 100,00 \\
\hline Total Biaya (VC+FC) & & & $2.900 .054,13$ & $8.209 .106,83$ & \\
\hline
\end{tabular}

Sumber: Data Primer Diolah, 2013

Pada Tabel 3 bibit yang digunakan pada daerah penelitian berupa stek ubi jalar ungu, tetapi satuan perhitungan tetap per kilogram. Jenis bibit yang dipakai adalah bervarietas L. Poir (ungu bergaris putih), dan sebenarnya tidak diperjual-belikan di pasar. Petani mendapatkanya dengan cara mengambil pembibitan hasil produksi sebelumnya atau dari produksi petani lain. Rata-tara 
biaya untuk bibit yang dikeluarkan oleh petani adalah sebesar Rp 37.816,38/Ut atau Rp 105.198,87/Ha, dengan harga rata-rata yang dikeluarkan adalah Rp $73,37 / \mathrm{Kg}$. Untuk luas rata-rata 0,36 hektar, jumlah bibit yang digunakan ratarata sebanyak 509,81 Kg/Ut atau sebesar $1.429,92 \mathrm{Kg} / \mathrm{Ha}$.

Walaupun penggunaan hanya satu macam pupuk saja, penggunaan tersebut tetap diperhitungkan sebagai biaya dimana harga beli pupuk ditentukan dari harga jual pupuk di kios-kios eceran pasar. Rata-rata penggunaan pupuk phonska pada usahatani ubi jalar ungu di daerah penelitian adalah sebesar $68,50 \mathrm{Kg} / \mathrm{Ut} / \mathrm{Mt}$ atau 191,67 Kg/Ha/Mt. Dengan besarnya biaya pupuk yang diperhitungkan adalah Rp 174.537,50/Ut atau Rp 486.833,33/Ha. Pada tabel 3 penggunaan biaya pupuk bila dipersentasekan mencapai 7,88 persen dari jumlah total biaya variabel. Menurut petani ubi jalar ungu mengapa hanya menggunakan satu macam pupuk kimia adalah karena tanah untuk usaha penanaman ubi jalar ungu masih subur dan ubi ini tidak memerlukan banyak pupuk, serta pupuk phonska merupakan pupuk lengkap yang sudah mengandung semua unsur pupuk yang dibutuhkan pada usahatani ubi jalar ungu. Penggunaan pupuk ini hanya dilakukan 1 kali pada usia tanaman mencapai 4 bulan. Dengan alasan yang dikemukakan petani jika terlalu sering dilakukan pemupukan, daun akan menjadi subur tetapi umbinya berkurang. Penggunaan pupuk kandang dilakukan satu kali dalam satu periode tanam ubi jalar ungu yaitu pada waktu melakukan pengolahan tanah atau ditebarkan saat membuat bedengan sebelum ubi ditanami. Menurut responden penggunaan pupuk kandang bermanfaat untuk menyuburkan tanah, karena banyak mengandung bahan organik sebagai unsur hara yang dibutuhkan tanaman. Rata-rata penggunaan pupuk kandang per periode per luas rata-rata 0,36 hektar untuk ubi jalar ungu sebesar 1.311,63 Kg/Ut/Mt atau $3.678,17 \mathrm{Kg} / \mathrm{Ha} / \mathrm{Mt}$. Pupuk kandang tersebut dapat diperoleh petani dari lingkungan sekitarnya, baik dari usaha sampingannya sebagai peternak maupun dari petani lain. Pupuk organik ini bisa berupa pupuk kandang baik kambing maupun sapi. Besarnya biaya yang dikeluarkan untuk satu priode tanam adalah sebesar Rp 232.293,93/Ut/Mt atau Rp 667.483,92/Ha/Mt.

Pada Tabel 3 terlihat besarnya biaya pupuk kandang adalah 10,81 persen dari total biaya variabel yang digunakan pada usahatani ubi jalar ungu untuk satu kali priode tanam di daerah penelitian. Tenaga kerja yang digunakan petani ubi jalar ungu dalam usahatani ubi jalar ungu adalah tenaga kerja manusia yang berasal dari dalam keluarga (TKDK) yaitu tenaga kerja pria dan wanita tanpa melibatkan tenaga kerja anak-anak, tenaga kerja merupakan biaya terbesar yang dikeluarkan oleh petani. Upah tenaga kerja dibedakan berdasarkan jenis kelamin, dan upah untuk satu hari kerja yaitu sebesar Rp. 40.000,- untuk pria dan Rp 30.000,- untuk wanita atau Rp 40.000,- setara HKP. Hari kerja wanita dihitung dengan HKO dan dikonversikan ke dalam HKSP. Rata-rata penggunaan tenaga kerja adalah sebesar 50,38 HKSP/Ut/Mt terdiri 
dari penjumlahan tenaga kerja laki-laki dan perempuan yaitu sebesar 22,80 HOK laki-laki dan 27,58 HOK perempuan atau sebesar 143,07 HOK/Ha/Mt. Besarnya biaya rata-rata yang dikeluarkan untuk tenaga kerja pada usahatani ubi jalar ungu di daerah penelitian adalah sebesar Rp 1.739.250,00/Ut/Mt atau $\mathrm{Rp}$ 4.917.166,67/Ha/Mt. Dari jumlah total biaya variabel yang dikeluarkan, biaya tenaga kerja merupakan biaya terbesar yang dikeluarkan yaitu sebesar 79,61 persen dari total biaya variabel. Rincian penggunan tenaga kerja dapat dilihat pada tabel berikut.

Tabel 4. Rata-rata Penggunaan Tenaga Kerja Dalam Keluarga (TKDL)

\begin{tabular}{clccr}
\hline No & \multicolumn{1}{c}{ Kegiatan } & Jumlah HKSP & $\%$ & Nilai (RP) \\
\hline 1 & Pengolahan lahan & 8,85 & 17,56 & $354.000,-$ \\
2 & Pembibitan & 5,20 & 10,32 & $156.000,-$ \\
3 & Penanaman & 5,23 & 10,38 & $156.750,-$ \\
4 & Penyiangan & 6,23 & 12,36 & $186.750,-$ \\
5 & Pembumbunan & 3,05 & 6,05 & $91.500,-$ \\
6 & Pemupukan & 1,23 & 2,44 & $48.000,-$ \\
7 & Panen & 20,61 & 40,90 & $746.250,-$ \\
\hline & Jumlah & $\mathbf{5 0 , 3 8}$ & $\mathbf{1 0 0 , 0 0}$ & $\mathbf{1 . 7 3 9 . 2 5 0 , -}$ \\
\hline
\end{tabular}

Sumber: Data Primer Diolah, 2013

Sewa lahan adalah besaran biaya yang keluarkan untuk untuk luasan lahan yang dimiliki oleh petani. Sewa lahan merupakan komponen biaya yang diperhitungkan bagi petani yang menggarap lahan sendiri (pemilik lahan). Besarnya sewa lahan untuk satuan hektar di daerah penelitian adalah sebesar $\mathrm{Rp} 4.000 .000,-/ \mathrm{Ha} /$ tahun. Rata-rata biaya sewa lahan yang dikeluarkan untuk satu kali musim tanam adalah sebesar Rp 656.250,-/Ut/Mt atau sebesar Rp 1.850.000,-/Ha/Mt atau 91,02 persen dari total biaya tetap. Pajak lahan adalah besaran biaya yang dikeluarkan untuk semua luasan lahan yang dimiliki petani dalam satu tahun. Rata-rata biaya pajak yang dikeluarkan petani ubi jalar ungu perluas lahan permusim tanam adalah sebesar Rp 6.563,98/Ut/Mt atau Rp $14.019,79 / \mathrm{Ha} / \mathrm{Mt}$. Besaran biaya pajak yang dikeluarkan 0.69 persen dari total biaya tetap yang dikeluarkan oleh responden di daerah penelitian. Besar kecilnya pajak yang dikeluarkan oleh petani tergantung oleh luas dan lokasi lahan yang dimiliki oleh petani responden. Komponen biaya tetap lainnya adalah biaya penyusutan. Biaya penyusutan terhadap alat-alat pertanian yang digunakan dalam usahataninya dapat dilihat pada tabel berikut. 
Tabel 5. Rata-rata Biaya Penyusutan Alat Usahatani Ubi Jalar Ungu di Desa Teladan

\begin{tabular}{|c|c|c|c|c|}
\hline \multirow{2}{*}{ No } & \multirow{2}{*}{ Jenis Alat } & \multicolumn{3}{|c|}{ Biaya penyusutan usahatani ubni jalar ungu } \\
\hline & & $(\mathrm{Rp} / \mathrm{Ut} / \mathrm{Mt})$ & $(\mathrm{Rp} / \mathrm{Ha} / \mathrm{Mt})$ & $\%$ \\
\hline 1 & Cangkul & $20.496,33$ & $65.326,88$ & 38,79 \\
\hline 2 & Parang & $7.857,12$ & $24.900,93$ & 14,79 \\
\hline 3 & Arit & $17.418,40$ & $54.020,83$ & 32,08 \\
\hline 4 & Ani-ani & $1.318,40$ & $4.292,82$ & 2,54 \\
\hline 5 & Sarung tangan & $6.387,50$ & $20.804,17$ & 12,35 \\
\hline & Total Biaya & $53.342,29$ & $168.403,97$ & 100,00 \\
\hline
\end{tabular}

Sumber: Data Primer Diolah, 2013

Berdasarkan Tabel 5 terlihat bahwa biaya penyusutan alat dengan ratarata luas tanam 0,36 Ha adalah sebesar Rp 53.342,29/Ut/Mt atau sebesar Rp 168.403,97/Ha/Mt. Jadi besarnya rata-rata biaya produksi usahatani ubi jalar ungu adalah sebesar Rp 2.900.054,13/Ut/Mt atau sebesar Rp 8.209.106,83/Ha/Mt.

\section{Analisis Produksi, Penerimaan dan Pendapatan Usahatani Ubi Jalar Ungu}

Produksi rata-rata tanaman ubi jalar ungu permusim tanam sebesar $3.385,25 \mathrm{Kg}$ untuk satu kali musim tanam. Dengan harga rata - rata sebesar Rp. 1870 per $\mathrm{kg}$, penerimaan total rata-rata ubi jalar ungu yang diperoleh adalah sebesar Rp 6.220.225/Ut/Mt atau sebesar Rp 17.693.400,00/Ha/Mt. Dari data ini, besarnya rata-rata pendapatan yang diterima petani ubi jalar ungu adalah $\mathrm{Rp}$ 3.320.170,87/Ut/Mt atau sebesar Rp 9.484.29,17/Ha/Mt. Dari hasil penelitian dapat dikatakan usahatani ubi jalar ungu di daerah penelitian telah memberikan keuntungan bagi petani karena pada saat itu harga ubi jalar ungu varietas L. Poir cukup tinggi.

\section{Analisis Efisiensi R/C Ratio}

Analisis efisiensi usahatani dilakukan untuk mengetahui apakah usahatani ubi jalar ungu yang dilakukan petani di Desa Teladan telah menguntungkan dan layak untuk dikembangkan. Efisiensi usahatani (R/C Ratio) merupakan perbandingan antara rata-rata penerimaan dan rata-rata biaya yang dikeluarkan pada usahatani ubi jalar ungu tersebut. Hasil estimasi didapatkan bahwa R/C Ratio yang diperoleh pada usahatani ubi jalar ungu sebesar 2,15 per hektar. Hal ini berarti bahwa setiap Rp 1000,- yang dikeluarkan petani dalam kegiatan usahatani ubi jalar ungu akan memperoleh penerimaan sebesar Rp 2.120/Ha/Mt. Berdasarkan kriteria R/C Ratio > 1 (Soekartawi, 2006), berarti usahatani ubi jalar ungu di Desa Teladan sudah efisien dan menguntungkan untuk diusahakan. 


\section{Karakteristik Responden Industri Rumah Tangga}

Pemilik home industri Zahra adalah ibu Surahtiyah yang berusia 57 tahun. Usia pemilik home industri termasuk pada usia produktif, usia produktif erat kaitanya dengan keadaan fisik, semangat dan tenaga untuk melakukan kegiatan usaha. Hal ini dapat menunjang usaha pengolahan untuk bekerja penuh dalam melakukan usaha sehingga dapat membantu tercapainya usaha yang optimal (Mubyarto, 1984).

Tingkat pendidikan yang dimiliki adalah Sekolah Menengah Atas (SMA) atau pendidikan formal mencapai 12 tahun. Dengan pendidikan non formalnya yang pernah diikuti satu kali selama 3 bulan yang diselengarakan oleh Dinas Perindustrian Dan Perdagangan Kabupaten Rejang Lebong. Hal ini menunjukkan tingkat pendidikan yang dimiliki oleh pemilik industri cukup tinggi sehingga dapat membantu cepatnya dalam pengadopsian inovasi baru. Pengalaman usaha yang dimiliki untuk pengolahan pangan sudah cukup lama yaitu sejak tahun 2005, tetapi untuk pengolahan ubi jalar ungu dilakukan selama 5 tahun ini. Lamanya pengalaman usaha pengolah ubi jalar ungu menunjukkan pemilik semakin terampil dalam pekerjaannya, sehingga akan dapat meningkatkan output yang dihasilkan.

\section{Analisis Nilai Tambah}

Analisis nilai tambah berguna untuk menguraikan proses produksi menurut sumbangan masing-masing faktor produksi, serta berguna untuk mengetahui distribusi nilai tambah terhadap tenaga kerja serta pengelola. Analisis nilai tambah ini dihitung menggunakan nilai rata-rata yang dikeluarkan dalam proses produksi pembuatan makaroni ubi jalar ungu dan analisisnya berdasarkan sumber dari nilai tambah menurut Hayami (1987).

Dari Tabel 6 menunjukkan bahwa hasil produksi pengolahan ubi jalar ungu menjadi makaroni adalah $32 \mathrm{Kg}$ / periode produksi. Tampak bahwa ada peningkatan output hasil olahan, karena adanya bahan tambahan/penolong yang digunakan untuk pembuatan makaroni tersebut. Nilai faktor konversi dihitung berdasarkan perbandingan pembagian antara nilai output yang dihasilkan dengan nilai input yang digunakan. Untuk menghasilkan sejumlah produk tersebut dibutuhkan ubi jalar ungu sebanyak 25 kilogram, sehingga faktor konversi adalah 1,28. Artinya setiap 1 kilogram ubi jalar ungu yang diolah akan menghasilkan 1,28 kilogram makaroni ubi jalar ungu. 
Tabel 6. Hasil Analisis Nilai Tambah

\begin{tabular}{llcr}
\hline No & \multicolumn{1}{c}{ Variabel } & Perhitungan & \multicolumn{1}{c}{ Nilai } \\
\hline \multirow{2}{*}{ Output, Input, Harga } & & \\
1 & Hasil Produksi (Kg/periode) & 1 & 32 \\
2 & Bahan Baku/Input (Kg/periode) & 2 & 25 \\
3 & Input Tenaga Kerja (Orang/periode) & 3 & 3 \\
4 & Faktor Konversi & $4=1 / 2$ & 1,28 \\
5 & Koefisien Tenaga Kerja & $5=3 / 2$ & 0,12 \\
6 & Harga Produk (Rp/Kg) & 6 & 40.000 \\
7 & Upah Rata-rata (Rp/HOK) & 7 & 30.000 \\
& Pendapatan Dan Keuntungan & & \\
8 & Harga Input Bahan Baku (Rp/Kg) & & 4.000 \\
9 & Sumbangan Input Lain/Penolong & & 5.736 \\
& (Rp/Kg) & $10=4 \times 6$ & 51.200 \\
10 & Nilai Output/Produk (Rp/Kg) & $11=10-8-9$ & 41.464 \\
11 & a. Nilai tambah (Rp/Kg) & $12=(11 \mathrm{a} / 10) \times 100 \%$ & 80,98 \\
& b. Rasio Nilai tambah (\%) & $13=5 \times 7$ & 3.600 \\
12 & a. Pendapatan tenaga kerja (Rp/Kg) & $14=(12 \mathrm{a} / 11 \mathrm{a}) \times 100 \%$ & 8,68 \\
& b. Imbangan Tenaga kerja (\%) & $15=11 \mathrm{a}-12 \mathrm{a}$ & 37,864 \\
13 & a. Keuntungan (Rp/Kg) & $16=(13 \mathrm{a} / 11 \mathrm{a}) \times 100 \%$ & 91,31 \\
\hline b. Tingkat keuntungan (\%) & & \\
\hline
\end{tabular}

Sumber: Data Primer Diolah, 2013

Tenaga kerja yang digunakan dalam proses pengolahan makaroni ubi jalar ungu adalah sebanyak 3 orang. Ketiga tenaga kerja tersebut adalah perempuan dan upah yang dibayarkan adalah sebesar Rp 30.000,-/HOK. Ketiga pekerja selalu bekerja sama mulai dari penyiapan input sampai produksi pembuatan makaroni ubi jalar ungu pada. Seluruh kegiatan produksi dalam satu kali proses produksi membutuhkan tenaga kerja sebanyak 3 orang. Jumlah orang kerja yang digunakan setelah dibagi dengan jumlah bahan baku yang digunakan diperoleh koefisien tenaga kerja sebesar 0,12. Nilai koefisien tenaga kerja ini menunjukkan banyaknya tenaga kerja yang diperlukan untuk memproduksi 1 kilogram bahan baku. Dari koefisien tenaga kerja dapat diartikan untuk mengolah satu kilo ubi jalar ungu menjadi makaroni ubi jalar ungu membutuhkan tenaga kerja sebanyak 0,12 HOK. Sementara itu sumbangan bahan lain/penolong yang digunakan untuk satu kali proses produksi adalah sebesar $\mathrm{Rp} 5.736,-/ \mathrm{Kg}$. Sumbangan bahan lain/penolong terdiri dari : gula, gandum, sagu, keju, minyak, dan input penolong lain yang digunakan, termasuk peralatan, bahan kemas dan bahan bakar. 
Dari perkalian faktor konversi dengan harga output diperoleh nilai produk dari makaroni ubi jalar ungu sebesar Rp 51.200,-. Nilai ini berarti setiap pengolahan satu kilogram ubi jalar ungu akan menghasilkan nilai makaroni ubi jalar ungu sebesar Rp 51.200,-/Kg. Disini terlihat bahwa nilai produk makaroni yang dihasilkan dalam kegiatan pengolahan ini lebih besar dibandingkan dengan harga satu kiligram bahan baku yang membentuknya. Nilai tambah yang diciptakan dari kegiatan pengolahan ubi jalar ungu menjadi makaroni ubi jalar ungu diperoleh dengan mengurangkan nilai produk dengan harga bahan baku ubi jalar ungu dan sumbangan input lain per kilogram. Nilai tambah yang diperoleh dari pengolahan adalah sebesar $\mathrm{Rp} 41.464,-/ \mathrm{Kg}$ dengan harga bahan baku ubi jalar ungu adalah $\mathrm{Rp} 4000,-/ \mathrm{Kg}$, dan sumbangan bahan lain/penolong Rp 5.736,-, dengan rasio nilai tambah yang diperoleh sebesar 80,98 persen. Artinya, dari Rp 41.464,-/Kg nilai produk, maka sebesar 80,98 persen merupakan nilai tambah dari pengolahan produk. Nilai tambah ini merupakan nilai tambah kotor bagi pengelola karena belum dikurangi dengan imbangan tenaga kerja.

Upah tenaga kerja yang dikeluarkan untuk kegiatan pengolahan persatu kali produksi sebesar Rp 30.000,-/HOK. Tenaga kerja tersebut selalu bekerja sama dalam sewaktu-waktu. Dalam satu kali proses produksi mencakup seluruh kegiatan dari pencucian sampai dengan pengemasan. Imbangan tenaga kerja didapatkan dari perkalian koefisien tenaga kerja dengan upah rata-rata tenaga kerja per hari per kilogram yaitu sebesar Rp 3.600,-. Persentase upah tenaga kerja terhadap nilai tambah adalah sebesar 8,68 persen. Hal ini berarti bahwa 8,68 persen dari nilai tambah penjualan merupakan imbalan yang diterima tenaga kerja. Angka menunjukkan bahwa industri pengolahan ubi jalar ungu bukanlah merupakan usaha yang padat tenaga kerja, bisa dikatakan usaha ini merupakan usaha yang padat modal sehingga tidak membutuhkan tenaga kerja yang terlalu banyak. Rata-rata pekerjaan telah menggunakan alatalat proses produksi guna memudahkan pekerjaan sehingga tidak membutuhkan tenaga kerja yang banyak. Dari penjualan makaroni ubi jalar ungu keuntungan yang berhasil diperoleh oleh industri rumah tangga Zahra adalah sebesar $\mathrm{Rp} 37.864,-/ \mathrm{Kg}$, dengan tingkat keuntungan yang diperoleh adalah 91,31 persen. Yang berarti bahwa 91,31 persen dari harga jual merupakan keuntungan yang diterima. Keuntungan ini merupakan nilai tambah bersih karena telah dikurangi dengan imbangan tenaga kerja.

Tingkat keuntungan yang tinggi diperoleh bukan dari nilai produk yang lebih tinggi tetapi melainkan dari nilai penjualan yang lebih banyak, selain itu menurut Zakaria (2000) interaksi antar tingkat teknologi, manajemen usaha, dan kualitas sumberdaya manusia pengolah akan menentukan tingkat produksi dan pandangan yang pada akhirnya akan menentukan besarnya nilai tambah yang dihasilkan. 


\section{SIMPULAN DAN SARAN}

\section{Kesimpulan}

Dari hasil dan pembahasan yang telah diuraikan diatas maka dapat ditarik kesimpulan sebagai berikut:

1. Faktor-faktor produksi yang berpengaruh nyata terhadap produksi ubi jalar ungu yaitu bibit, pupuk phonska pada tarap kepercayaan $90 \%$ dan tenaga kerja berpengaruh nyata terhadap produksi pada tarap kepercayaan $80 \%$.

2. Biaya produksi usahatani ubi jalar ungu adalah sebesar Rp 2.900.054,13/Ut/Mt atau Rp 8.209.106,83/Ha/Mt, Penerimaan sebesar $\mathrm{Rp} \quad 6.220 .225,-/ \mathrm{Ut} / \mathrm{Mt}$ atau $\mathrm{Rp}$ 17.693.400,-/Ha/Mt. Sehingga besarnya pendapatan adalah Rp 3.320.170,87/Ut/Mt atau sebesar Rp 9.484.293,17/Ha/Mt.

3. Nilai R/C Ratio lebih dari satu, yaitu sebesar 2,15. Sehingga usahatani ubi jalar ungu di Desa Teladan efisien dan menguntungkan.

4. Nilai tambah yang diperoleh dari pengolahan ubi jalar ungu menjadi makaroni adalah sebesar Rp 41.464,-/ Kg/produksi dengan rasio nilai tambah yang diperoleh sebesar 80,98 persen. Nilai tambah ini merupakan nilai tambah kotor bagi pengelola karena belum dikurangi dengan imbangan tenaga kerja. Keuntungan penjualan sebesar $\mathrm{Rp} 37.864,00 / \mathrm{Kg}$, atau 91,31 persen, yang berarti bahwa 91,31 persen dari harga jual merupakan keuntungan yang diterima industri rumah tangga Zahra.

\section{Saran}

Berdasarkan hasil dan pembahasan serta kesimpulan, maka disarankan:

1. Upaya untuk meningkatkan usahatani ubi jalar ungu dapat dilakukan salah satunya dengan cara memperhatikan penggunaan faktor-faktor produksi yang dapat mempengaruhi produksi ubi jalar ungu. Variabel yang memiliki nilai koefisien yang berpengaruh nyata seperti bibit, pupuk phonska dan tenaga kerja penggunaannya masih dapat ditambahkan agar menjadi lebih optimal tingkat usahanya, input-input ini bisa ditingkatkan lagi masing-masing sebesar 71,60 persen untuk bibit, 72,30 persen untuk pupuk phonska, dan 80 persen untuk tenaga kerja. Hal ini dikarenakan setiap penambahan tersebut dapat meningkatkan produksi ubi jalar ungu. Untuk meningkatkan pendapatan petani 
dapat melakukan penambahan luas tanam untuk tanaman ubi jalar ungu varietas L. Poir.

2. Bagi pengolah Industri Rumah Tangga ZAHRA masih perlu meningkatkan produksinya karena pengolahan ubi jalar ungu memberikan nilai tambah yang tinggi dan menguntungkan, tetapi perlu diperhatikan juga peningkatan upah terhadap tenaga kerja.

3. Bagi pemerintah melalui BIPP, Dinas Pertanian, dan Dinas Perdagangan dan Perindustrian, pengembangan budidaya dan pengolahan ubi jalar ungu mutlak diperlukan, sehingga petani termotivasi untuk terus menanam dan memperluas tanaman secara kontinu varietas L. Poir.

4. Untuk kontinuitas ketersedian bahan baku bagi Industri Rumah Tangga ZAHRA disarankan untuk membuat sistem kemitraan dengan petani ubi jalar ungu varietas L.Poir.

\section{DAFTAR PUSTAKA}

Hayami, Y. Toshihiko Kawagoe, Yoshinori Marooka, and Masjidin Siregar. 1987. Agricultural Marketing and Processing In Up Land Java. A Perspective From A Sunda Village. CGPRT Center. Bogor. 75 p.

Mubyarto. 1984. Pertanian Edisis Ketiga Pengantar Ekonomi. LP3ES. Jakarta.

Nazir. 1983. Metode Penelitian. Ghalia Indonesia. Jakarta.

Nurmalina, R. 2008. Analisis Indeks dan status Keberlanjutan Sistem Ketersediaan

Beras di Beberapa Wilayah di Indonesia. Jurnal Agro Ekonomi. 26 (1) : 47-79.

Rukmana, R. 1997. Ubi Jalar Budidaya dan Pasca Panen. Penerbit Kanisius. Yogyakarta.

Soekartawi. 1990. Teori Ekonomi Produksi dengan Pokok Bahasan Analisis CobbDouglas, Edisi 1. PT Raja Grafindo Persada. Jakarta. 2006. Analisis Usaha Tani. UI Press. Jakarta.

Zakaria, W.A. 2000. Analisis Nilai Tambah Ubi Kayu pada Beberapa Agroindustri Berbasis Ubi Kayu di Provinsi Lampung. Sosial Ekonomi volume VI (2) : 118-125. 